Article

\title{
Global Bank Capital and Liquidity after 30 Years of Basel Accords
}

\author{
Harald Benink 1,2,3 \\ 1 School of Economics and Management, Tilburg University, 5000 LE Tilburg, The Netherlands; \\ h.a.benink@tilburguniversity.edu \\ 2 Financial Markets Group, London School of Economics, London WC2A 2AE, UK \\ 3 European Shadow Financial Regulatory Committee, 5000 LE Tilburg, The Netherlands
}

Received: 30 December 2019; Accepted: 2 April 2020; Published: 16 April 2020

\begin{abstract}
In this paper we analyze the effectiveness of more than 30 years of efforts by international banking supervisors, working together in the Basel Committee on Banking Supervision, to harmonize capital and liquidity standards for internationally active banks. Notwithstanding the great efforts and progress made by international banking supervisors since the financial crisis of 2007-2009, two important issues require further attention. First, although bank capital ratios have been raised significantly since the recent financial crisis, they are still at historically low levels. In a world in which global debt ratios have risen even further during the past decade, this is a worrying signal of fragility in the global financial system. Second, bank liquidity requirements may have become too complex and could also have unintented and unpredictable interaction effects with bank capital requirements.
\end{abstract}

Keywords: bank capital; bank liquidity; basel committee; great financial crisis

\section{Introduction}

The debate on bank capital and liquidity is an old one (see, for instance, Goodhart 2008; Kaufman 1994), but obtained new momentum after the Great Financial Crisis (GFC) of 2007-2009.

In this paper, we analyze the effectiveness of more than 30 years of efforts by international banking supervisors, working together in the Basel Committee on Banking Supervision, to harmonize capital and liquidity standards for internationally active banks. The financial crisis of 2007-2009 is an important milestone for this analysis, given the fact that many banks in Europe and the United States received unprecedented levels of liquidity and capital support from central banks and governments (taxpayers) in order to avoid bank runs and bankruptcy.

In Section 2, we analyze whether the recent financial crisis should be seen as primarily a solvency or a liquidity crisis. In Section 3, we revisit the literature on financial fragility. Next, we provide a critical analysis of the Basel Committee's recent initiatives to raise bank equity capital requirements (Section 4) and to introduce bank liquidity requirements (Section 5).

In Section 6, the paper ends with some concluding remarks. Notwithstanding the great efforts and progress made by international banking supervisors since the financial crisis of 2007-2009, two important issues require further attention. First, although bank capital ratios have been raised significantly since the recent financial crisis, they are still at historically low levels. In a world in which global debt ratios have risen even further during the past decade, this is a worrying signal of fragility in the global financial system. Second, bank liquidity requirements may have become too complex and could also have unintended and unpredictable interaction effects with bank capital requirements. 


\section{The Great Financial Crisis of 2007-2009: A Solvency or Liquidity Crisis?}

The Great Financial Crisis of 2007-2009 was, arguably, the biggest banking and financial crisis since the banking failures and financial panic of the Great Depression in the 1930s. In academic and regulatory circles, a lot of discussion has taken place over the past decade, as noted later in this section, about the question of whether the banking crisis of 2007-2009 was primarily a solvency crisis or a liquidity crisis. This question is important given the fact that international banking regulators, working together in the Basel Committee on Banking Supervision, decided to increase bank equity capital requirements and also to introduce bank liquidity requirements as part of their regulatory response to the crisis (the Basel III Accord, which was adopted in December 2010).

In a recent seminal paper, Thakor (2018) concluded, based on an extensive literature review covering some 30 recent papers published over the past decade, that the 2007-2009 Great Financial Crisis (GFC) was primarily an insolvency risk crisis that caused liquidity to flee the system.

Thakor (2018) noted that, while proponents of the view that the GFC was a liquidity crisis acknowledge that there were insolvency risk forces at work, they reason that the direction of causality was from illiquidity to insolvency. Contrary to this, proponents of the insolvency risk viewpoint propose that asset prices declined due to a shock to fundamentals, and this caused the equity values of highly leveraged institutions to fall, which then diminished their short-term borrowing capacity. Liquidity dried up because investors were unwilling to finance institutions that had debt overhang problems or were insolvent.

After studying the empirical evidence presented in recent papers on the GFC, Thakor (2018) concluded that the empirical evidence strongly indicates that this was an insolvency risk crisis, not a liquidity crisis. In his view, there are four strands of research that provide this evidence.

First, if the GFC was a liquidity crisis, it should have caused funding access to dry up for all institutions. The empirical evidence for the U.S., however, is that the majority of commercial and investment banks did not experience diminished funding during the crisis and did not engage in the fire sales predicted to accompany liquidity crises. The evidence also indicates that the institutions that did experience liquidity shortages during the crisis were those whose insolvency risk had risen due to a deterioration in asset values.

Second, there is empirical evidence that the massive withdrawals from money market mutual funds (MMFs) during 2008 were not precipitated by a market-wide liquidity crunch that caused only a run on those funds. Rather, these withdrawals were due to asset risk and insolvency concerns.

Third, in direct contradiction to the liquidity crisis hypothesis, there is substantial evidence that banks with higher capital ratios were less adversely affected by the crisis. Specifically, banks with higher capital ratios were more likely to survive the crisis and gain a market share during the crisis, took fewer risks prior to the crisis, and had smaller contractions in lending during the crisis.

Fourth, Thakor cited studies on the London Interbank Offered Rate (LIBOR)- Overnight Index Swap (OIS) spread, which is the difference between the three-month LIBOR and the three-month OIS rate. This spread reflects both liquidity and credit risks. Studies have documented that the spread increased sharply in August 2007 and stayed high. The huge liquidity injections by the Federal Reserve during 2008 should have lowered the spread if this was a liquidity crisis. Instead, the spread increased further. It only began to come down when insolvency risk was directly addressed, with the U.S. government infusing equity capital into banks.

On the basis of his review of the recent literature, Thakor (2018) concluded that the appropriate regulatory response should be to increase capital requirements in order to reduce solvency risk, not to freeze hundreds of billions of dollars into immobility by requiring banks to invest them in "high-quality liquid assets" (as part of the new bank liquidity requirements).

More generally, according to Thakor, lowering or eliminating bank liquidity requirements while increasing bank capital requirements will reduce the states in which banks find market access to short-term funding drying up—-thereby reducing their reliance on the central bank spigot—and free 
up more loanable funds for banks to invest and foster economic growth. It will also have the benefit of improving the efficiency, transparency, and simplicity of regulation.

The joint regulation of bank liquidity and bank capital under Basel III started a new and rich literature. As noted by DeYoung, Distinguin, and Tarazi (DeYoung et al. 2018), the liquidity of a bank's assets, the stability of a bank's liabilities, and a bank's desired levels of equity capital are interrelated in ways that are not fully understood by regulators and researchers. In addition, in a recent paper, Carletti, Goldstein, and Leonello (Carletti et al. 2018) studied the interdependence of bank capital and liquidity by building a global game model to analyze the interdependent effects of bank capital and liquidity on the likelihood of solvency- and liquidity-driven crises.

\section{Financial Fragility}

Hyman Minsky was one of the first authors to introduce the term financial fragility. Minsky (1977) discussed financial fragility as the opposite of financial robustness. In a fragile financial system, continued normal functioning can be disrupted by a not-unusual event. In this sense, a fragile system is more susceptible to future outbreaks of financial disorder.

In his famous paper, Knight (1921) argued that one can distinguish between three types of probability, namely a priori probability, statistical probability, and estimates or judgments. The first two cases of probability are called risk by Knight. The third case embodies nonmeasurable probability and is referred to as (true) uncertainty.

\subsection{Financial Fragility in a Risk/Uncertainty Framework}

The distinction between risk and uncertainty underlies the extreme poles between theories of financial fragility inspired by neoclassical theory (risk) and those theories based on post-Keynesian thinking (uncertainty) (as noted by Benink (1996)).

The neoclassical framework focuses on rational expectations and efficient markets. In a rational expectations world, economic agents know the correct and objective probability distribution, which enables them to correctly price financial assets (efficient market hypothesis). In such a world, defaults represent bad outcomes ex post, rather than a systematic misperception of the true ex ante odds. The famous Nobel Prize Laureate Merton Miller can be regarded as an advocate of this view (see, for instance, Miller 1991).

Although the financial innovation and deregulation process of the 1980s went together with a rise in debt ratios, this does not necessarily imply overleveraging. The increase in the aggregate debt/equity ratio, as seen from a macroeconomic perspective, reflects changing preferences of households for holding wealth (Miller 1988). Higher debt ratios and increased financial fragility can be considered to be a rational choice of risk-aware agents in financial markets. Increased financial fragility may increase the likelihood of periods of financial disorder, but it should not automatically be considered to be an undesirable thing or a rationale for increased regulation by international supervisory authorities. If risks are known and correctly priced by market participants, then these periods of financial disorder are unlucky, but calculated events.

The post-Keynesian framework of financial fragility is completely the opposite of the neoclassical one and focuses on irrational bubbles and euphoria. The heart of the argument lies in a different perception of the world: uncertainty instead of risk, which precludes the framework of rational expectations and efficient markets.

\subsection{The Great Financial Crisis of 2007-2009}

At a conference on "Coping with Financial Fragility and Systemic Risk", which was organized at Maastricht University in the Netherlands in September 1994 (the conference proceedings were published in 1995; see Benink 1995), one of the keynote speakers was Andrew Crockett, the new general manager of the Bank for International Settlements. In his speech Crockett (1995): 
The ability of some derivative products to significantly increase the leverage of market participants may increase aggregate uncertainty. I would also conjecture that because of the fundamental lack of transparency of some financial products and the difficulty of evaluating risk associated with them, the resulting concentration in some derivatives markets creates uncertainty externalities in other closely related markets. As a result of the close cross-market linkages, the uncertainty externalities cannot easily be segmented in periods of market volatility and stress. As participants seek to shield themselves against the impact of an event whose timing or probability of occurrence cannot be estimated, markets may at times experience an erosion of liquidity, possibly leading to difficulties in other markets.

Crockett spoke his words exactly 14 years before the fall of Lehman Brothers in September 2008. Further, in August 2007, the first phase of the great financial crisis had already emerged, when banks stopped lending to each other due to concerns about potential losses, and there were implications for banks' capital buffers in terms of portfolios of U.S. subprime mortgage loans that had been securitized and sold on financial markets to international investors, notably in Europe. In addition, in Europe, in January 2008 (eight months before the fall of Lehman Brothers), regulatory capital requirements for large banks in Europe were even reduced as part of the implementation of the Basel II Accord, notwithstanding the fact that banks had stopped lending to each other due to concerns about each other's solvency. Warnings against these lower capital buffers in spring 2008 were ignored (see, for instance, Benink and Kaufman 2008).

Securitization, special purpose vehicles (SPVs), and investment banks within the shadow banking system contributed substantially to the crisis, which came to its peak after the fall of Lehman Brothers. Policymakers in the U.S. thought that Lehman Brothers, being an investment bank, could be allowed to fail without serious repercussions. This proved to be a mistake, since Lehman was strongly interconnected with the conventional banking system as an important counterparty for hedging and trading activities, notably in the credit default swap market. Lehman's failure had important indirect effects on the banking system as well, since the liquidity of money market instruments declined and even dried up in some markets. These direct and indirect connections between the shadow banking system and the conventional banking system contributed to the severity of the banking crisis, both in the U.S. and in Europe (see, for instance, the statement on shadow banking by the European Shadow Financial Regulatory Committee 2016, March).

The Great Financial Crisis of 2007-2009 clearly contains elements of overleveraging and overindebtedness, excessive risk taking, the underpricing of risk, and euphoria. It also led to a reappraisal of the work of Hyman Minsky. In the words of Wolf (2014), the chief economics commentator of the Financial Times, in his column on 3 September 2014:

The financial crises and the years of economic malaise that followed represent profound failures of the economy and of policy. Above all, they were failures of understanding. We have learnt much since. But we have not learnt enough to avoid a repeat of this painful experience. We retain unbalanced and financially fragile economies. We need to be substantially more radical than we have dared to be hitherto.

Policymakers did not expect the crises that began in 2007. Not only did they not expect them, many prided themselves on their role in creating something called the "great moderation". As long as inflation was stable, they believed, everything would be for the best in the best of all possible economic and financial worlds.

That was the pre-crisis "old orthodoxy". Those in charge saw little danger in the rapid growth of credit; they were largely unconcerned by rising leverage; they thought financial innovation added to rather than reduced stability; and they believed it was easier to clean up after asset-price bubbles than to prevent them from growing in the first place.

On all this they were proved wrong, as the late and disregarded Hyman Minsky had sought to warn them. Among his many insights into how financial systems actually work, as 
opposed to how too many economists believed they did, was his realization that stability ultimately destabilizes.

A similar analysis on the causes of the GFC of 2007-2009 was presented by Rajan (2010).

\subsection{Bank Capital and Liquidity}

The evaporation of bank capital as well as bank liquidity was clearly an important part of the Great Financial Crisis. In the next two sections, we analyze the efforts of the Basel Committee on Banking Supervision in setting bank capital and liquidity requirements.

\section{Thirty Years of Basel Accords Aimed at Strengthening Bank Capital}

In December 2017, the Basel Committee on Banking Supervision, the world's leading committee (consisting of banking supervisors from more than 25 countries), published the agreement "Basel III: Finalizing Post-Crisis Reforms". This newest Basel Accord is the latest stage in the process, which started more than 30 years ago, of harmonizing bank capital and liquidity standards among internationally active banks.

The harmonization of bank capital standards started more than 30 years ago when, in early 1988, the Basel Committee published the "International Convergence of Capital Measurement and Capital Standards" (Basel Committee on Banking Supervision 1988), which came to be known as the Basel I Accord. At that time, after the Latin American sovereign debt crisis of the early 1980s, Basel I was the first attempt at an international harmonization of the definition of bank capital and of the amount of capital that banks are required to hold. One of the weaknesses of Basel I was that all loans to the private sector were allocated the same risk weight and regulatory capital requirement, thereby providing incentives to banks to focus on the riskier loans, which has a higher expected return (regulatory capital arbitrage). Basel II aimed at addressing this problem.

The Basel II Accord, entitled "International Convergence of Capital Measurement and Capital Standards-A Revised Framework" (Basel Committee on Banking Supervision 2004) was adopted in June 2004 and implemented in Europe starting in January 2008. Basel II allowed the most sophisticated banks to design internal risk models in order to calculate how much capital they need to have, thereby mitigating the problem of Basel I of regulatory capital arbitrage. However, the possibility of designing their own risk models provided incentives to many banks to reduce the risk estimates in their loan portfolios and hence allowed them to significantly reduce their required amounts of capital.

After the fall of Lehman Brothers in September 2008, which was followed by a severe banking crisis in both the U.S. and Europe, international bank supervisors realized that bank capital levels had to be raised substantially. The Basel III Accord of December 2010, entitled "Basel III: A Global Regulatory Framework for More Resilient Banks and Banking Systems" (Basel Committee on Banking Supervision 2010a), addressed these concerns by narrowing the definition of capital (i.e., less use of hybrid debt instruments counting as part of capital) and by increasing the required capital ratios.

In Europe, the Basel III Accord was translated into binding legislation, in particular through the adoption in 2013 of the "Capital Requirements Regulation (CRR)" and the "Capital Requirements Directive IV (CRD IV)". Moreover, as this occurred within the ambit of the European Banking Union, a single supervisory mechanism (SSM) was introduced, allocating supervisory responsibilities to the European Central Bank, as well as a single resolution mechanism (SRM), creating a new resolution authority (i.e., the "Single Resolution Board").

Adequate supervision and resolution of the banking sector may be even more important in Europe than in the U.S., because in Europe, the financial system is more bank-based and therefore more likely to have a more significant impact on the economy when problems arise.

The Basel III Agreement of December 2017 (on finalizing postcrisis reforms) importantly addresses the incentive problems associated with banks minimizing calculated risk weights, using their internal risk models, in order to minimize regulatory capital requirements. In order to mitigate these incentives, 
so-called floors were defined: a percentage of standardized risk weights set by supervisors, below which capital is not allowed to fall (Basel Committee on Banking Supervision 2017).

Due to the potential impact of the floors, the Basel Committee decided to implement the floors over a phased-in period of five years. The output floors will be implemented as of January 2022 and will initially be set at $50 \%$ of standardized risk weights and then will be increased by $5 \%$ each year between 2022 and 2026 until it is set at 70\%, before finally increasing to 72.5\% in 2027 (PricewaterhouseCoopers 2018).

Notwithstanding the clear benefits of the latest Basel III agreement on mitigating the outcome of internal risk models on bank capital levels, it is interesting to note that there has been substantial academic work, from as early as the early 2000s, warning against gaming, manipulation, and calibration when banks are allowed to use their own models (see, for example, Benink and Wihlborg 2002). For a period that has lasted too long, banking supervisors have been denying the potentially perverse incentives many banks may have to underestimate credit risk in order to minimize the amount of capital.

More fundamentally, notwithstanding the current progress in raising bank capital ratios, the problem remains that bank capital is still at historically low numbers. For instance, in a study on the historical evolution of bank capital ratios in 10 European countries, Benink and Benston (2005) showed that bank capital ratios (defined as equity capital divided by total assets, the so-called leverage ratio) were still around $15 \%$ in the early 1930s, were halved to about $7.5 \%$ in the late 1940 s, and have been stabilized at around $6 \%$ since the 1950s (see Figure 1), thereby creating a fragile banking system prone to crises (e.g., what happened during the GFC of 2007-2009). In contrast to banks, the capital ratios of nonfinancial companies in the same set of 10 European countries have been fluctuating in the range of 30-50\% during recent decades, before the Great Financial Crisis started in September 2008 (see Figure 2).

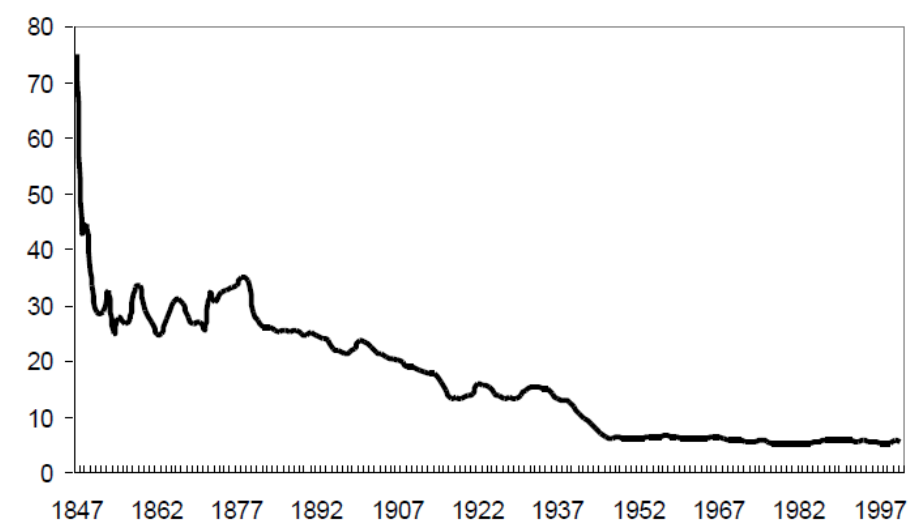

Figure 1. Average Capital/Asset Ratio of Commercial Banks Europe 1847-2001. Source: Benink and Benston (2005).

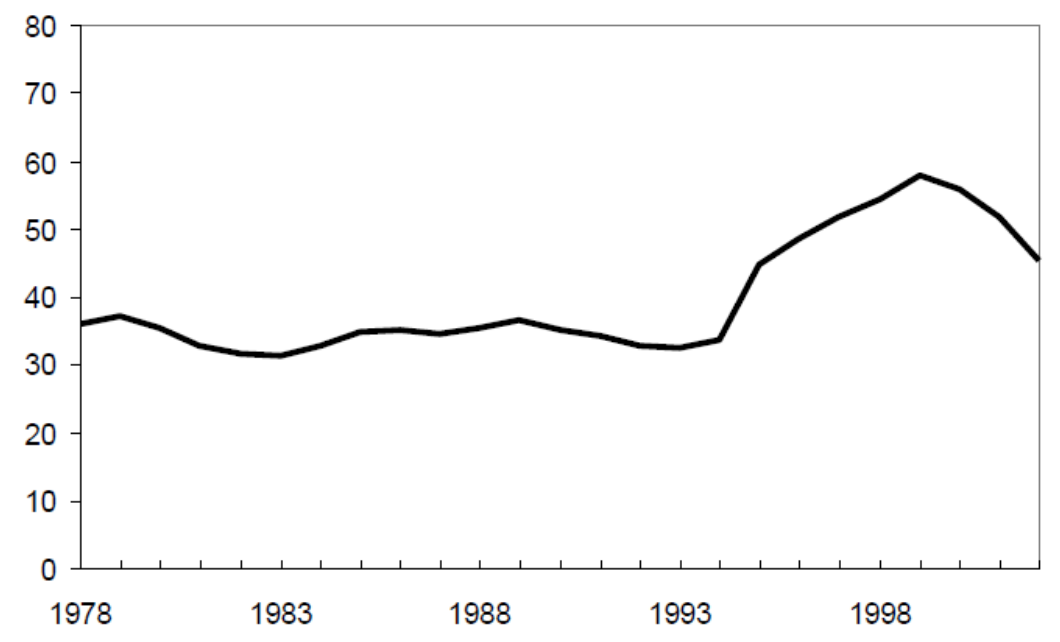

Figure 2. Average Capital/Asset Ratio of Non-Financial Companies Europe 1978-2002. 
It is interesting to note that the empirical evidence on bank capital ratios is quite similar for the 10 European countries, notwithstanding the fact that bank and country characteristics can vary substantially.

Very similar empirical evidence on the historical decline of bank capital ratios exists for banks in the U.S., as was presented by Greenspan in The Economist in December 2008 (see Figure 3).

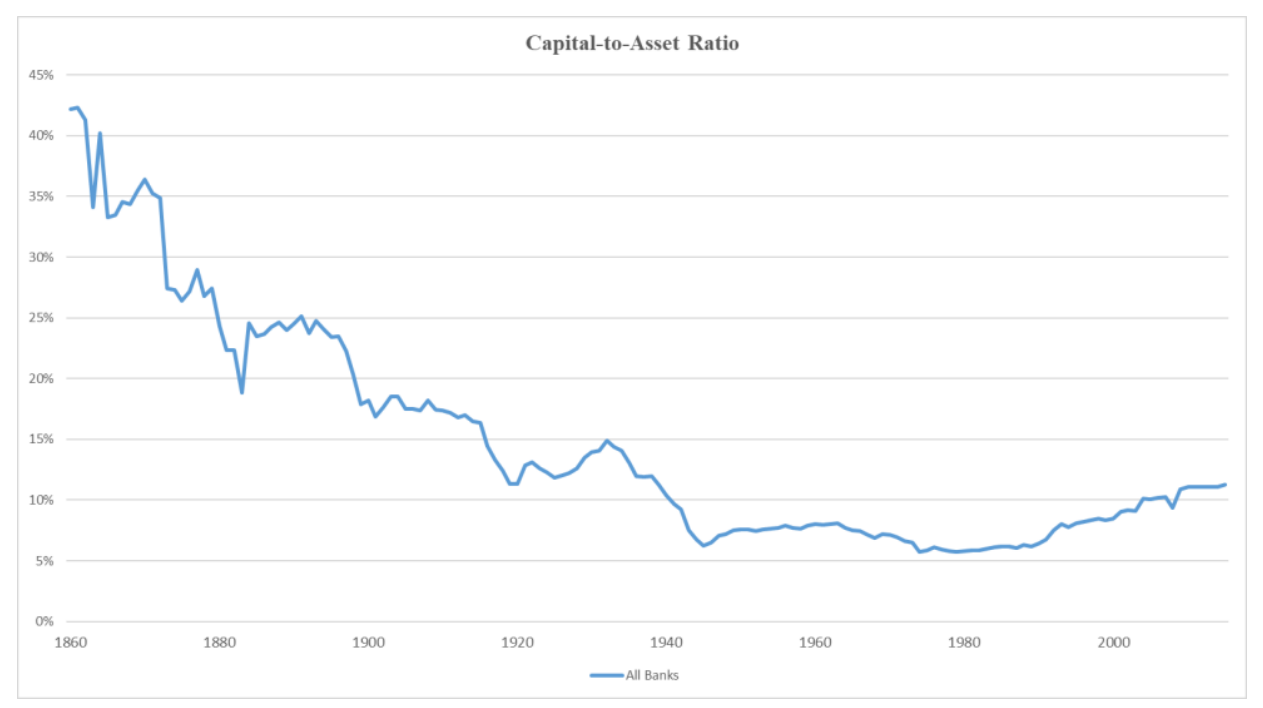

Figure 3. Capital-to-Asset Ratio. Source: Historical Statistics of the United States: Colonial Times to 1957. U.S. Department of Economics, Bureau of the Census, 1961.

The Great Depression and banking crises of the 1930s led to banking regulators and supervisors saying that a systemic banking crisis should never happen again. As a response, both in Europe and the U.S., explicit guarantees, such as deposit insurance, were introduced. More importantly, implicit guarantees such as too big to fail led to the perception among bond holders and holders of subordinated debt that they would be bailed out by taxpayers if a large bank faced potential bankruptcy. Because of these guarantees, bank capital ratios were allowed to fall from $15 \%$ toward historically low numbers. In essence, investors in markets of bank debt endorsed lower capital ratios, and regulators facilitated this by reducing capital requirements.

In our view, the recent Basel III finalization proposals do not sufficiently address the historical evidence on adequate capitalization of banks. Even for a group of global, systemically important banks, which due to their interconnectedness can be expected to be prominent in propagating banking crises, the proposals contain an absolute minimum of the required leverage ratio (the maximum is $4.5 \%$, including a surcharge for systemic risk for a group of 30 global systemically important financial institutions). This is still far below the ratios banks used to have before the introduction of guarantees such as deposit insurance and too big to fail.

Although bank capital ratios have risen significantly since the recent financial crisis, they are still at historically low levels, thereby making it unlikely that banks will be able to withstand future crises without having to be bailed out by taxpayers. The introduction of regular bank stress tests may be a useful tool, but these test around bank capital ratios, which are still, from a historical point of view, relatively low. In a world in which global debt ratios have risen even further during the past decade, this is a worrying signal of fragility in the global financial system.

Therefore, we need to be much more ambitious in raising bank capital levels, preferably in the form of Tier 1 equity capital ratios (or leverage ratio) of 10\% to 15\%, as suggested by Benink and Benston (2005) and Greenspan (2008). This ambition, which is still lower than the increases in bank capital advocated by Admati and Hellwig (2010), could be implemented by banks issuing new shares, and thus retaining net profits, and by banks issuing contingent convertible $(\mathrm{CoCo})$ bonds that mandatorily are converted 
into equity when a solvent bank's capital ratio falls below a certain threshold. An advantage of CoCo bonds is that they increase market discipline, thereby mitigating the potential incentives of banks to increase risk-taking due to the increase in bank capital.

Some may argue that, although Tier 1 equity capital ratios may be at historically low numbers, the total loss absorption capacity (TLAC) of banks is substantially higher due to the fact that some categories of unsecured creditors (for instance, holders of subordinated debt and common bond holders) are supposed to take losses through a bail-in.

Although the strategic orientation of TLAC may be a promising avenue in the long-term, currently, there are clearly issues with respect to the credibility of the bail-in mechanism, as was demonstrated by recent implementation problems in Germany and Italy. These credibility problems are related to exemptions with respect to not having to apply a bail-in in the case of systemic risk and precautionary recapitalizations (see, for the European case, the European Shadow Financial Regulatory Committee 2014). Because of this, losses will not be absorbed by unsecured debt holders. Therefore, there is still a need for higher equity capital buffers, as proposed above.

Naturally, this ambition cannot be realized within a few years. But why not define a transition period of, for instance, seven years? Looking at current levels of net profits of the large banks in Europe and the U.S., they could easily meet a substantial part of the higher equity capital standards by retaining only part of their net earnings during this period. The result would be a more resilient banking system that would be better able to withstand adverse economic shocks without having to resort to bail-outs by taxpayers.

\section{Basel III: Strengthening Bank Liquidity}

In December 2010, besides the Basel III Accord, which focused on bank capital, the Basel Committee also published the Basel III Accord, which focused on bank liquidity, under the title "Basel III: International Framework for Liquidity Risk Measurement, Standards and Monitoring" (Basel Committeee on Banking Supervision 2010b).

In the accord, international bank regulators agreed, for the first time, on minimum liquidity requirements for banks. Two liquidity measures were defined, i.e., the liquid coverage ratio and the net stable funding ratio.

The liquid coverage ratio (LCR) aims to ensure that a bank maintains an adequate level of high-quality liquid assets that can be converted into cash to meet its liquidity needs for a 30-calendar-day horizon under a significantly severe liquidity stress scenario that is specified by supervisors.

The net stable funding ratio (NSFR) aims to ensure that long-term assets are funded with at least a minimum amount of stable liabilities in relation to their liquidity risk profiles. It aims to limit overreliance on short-term wholesale funding during times of buoyant market liquidity and to encourage better assessments of liquidity risk across all on- and off-balance sheet items.

In October 2013, the Shadow Financial Regulatory Committees of Asia, Australia-New Zealand, Europe, Japan, Latin America and the United States (2013), which are networks consisting of well-known professors and other independent experts, issued a joint statement entitled "Misdiagnosis of Crisis Has Led to Botched Liquidity Regulation". In this statement, they criticized the LCR and advocated an alternative, the simple liquidity ratio.

In the view of the shadow committees, the Basel Committee's response to the Great Financial Crisis of 2007-2009 was based on a misdiagnosis. The lack of recognition of losses from the original subprime crisis delayed recovery, and economies worldwide are still suffering the consequences. The fundamental cause of this recent crisis was insolvency problems in the U.S. and Europe rather than a lack of liquidity, a point also made by Thakor (2018) in his extensive literature review a few years later.

For example, it was uncertainty about which banks had a high exposure to bad assets that led to a collapse in the functioning of the interbank money markets. We also observed a significant widening in the credit risk spreads between bank-issued paper and the government-issued alternative. 
The Basel Committee's approach was to put forward minimum solvency as well as liquidity requirements. In the view of the shadow committees, this happened due to a continued misunderstanding of the role that liquidity problems, relative to solvency problems, played in the recent financial crisis. Liquidity problems were symptomatic of underlying solvency problems. Hence, what is needed is not a regulation of minimum required liquidity but a clear indicator of the liquidity deficiency of an institution.

The committees instead proposed an alternative for the measurement and disclosure of liquidity that would rely on an indicator that encourages transparency in an institution's short-term funding needs and in its ability to meet those needs from its liquid assets without incurring losses or extraordinary reliance on central bank funding.

Imposing binding liquidity requirements as a means of buying time to deal with a troubled institution facing insolvency may increase the problem, which ultimately may spill over to the rest of the banking sector. Central banks still need to fulfill the traditional role of the lender of last resort for all solvent institutions that need temporary liquidity assistance. In the global financial crisis, such temporary facilities became protracted because the underlying solvency problems were not recognized and addressed.

\subsection{Key Attributes for an Effective Liquidity Indicator}

Good liquidity management by banks is critical to their ability to survive stressful situations, and it is therefore important that banks measure their liquidity positions appropriately and manage them carefully. This is relevant not just for internal bank management, but also for supervisors and for counterparties who ultimately may bear some of the risks arising from poor liquidity management. Indeed, a crucial feature of the proposal by the shadow committees is that liquidity positions should be publicly disclosed in a form that is easy for outsiders to understand and monitor. The resulting market discipline can help to ensure better management of liquidity risk by individual banks. This is at odds with longstanding bank and regulatory instincts to hide and disguise banks' financial conditions.

In the view of the shadow committees, a liquidity indicator should have the following attributes. First, the indicator should be simple to calculate and verify, and second, the measure should be easy to interpret for both supervisors and the market relative to some specified degree of stress. Third, the regulation based on the indicator should be simple to administer from the supervisor's point of view and not onerous to comply with from the bank's point of view. Fourth, a reliable liquidity monitoring regime would also reduce the problem of asymmetric information that underlies most liquidity problems. Finally, the liquidity indicator should be comparable across banks, but should allow for differences in business models.

Under the approach proposed by the committees, institutions would be free to disclose any additional data that they believe would help the market better understand their liquidity position, but the proposed indicator would ensure that at least one measure could be readily compared across institutions.

\subsection{Shadow Proposal for a Simple Liquidity Indicator}

The shadow committees recommended the use of a simple liquidity indicator (SLI) that should reveal potential concerns of liquidity mismanagement at a financial institution. This SLI gauges the ability of the financial institution to survive in a crisis when it becomes prohibitively expensive to attract new funding.

The numerator of the SLI is defined as those high-quality liquid assets that do not depend on a well-functioning secondary market for liquidity or on extraordinary reliance on the central bank. Given institutional differences across countries, the details of the measure would vary.

The denominator of the SLI aims at capturing liquidity needs during a worst-case stress event. The shadow committees proposed using recalculated cumulative net cash flows over the 
preceding 30 days based on a stress assumption that the institution would be unable to roll over all uninsured liabilities.

An advantage of the SLI compared to the LCR proposed by the Basel Committee is that it is easy to compute and would be more difficult to game.

The liquidity coverage ratio (LCR) proposed by the Basel Committee starts with a similar concept, but it gets complicated quickly. The LCR is calculated by dividing the high-quality liquid assets (HQLAs) held by the bank by the assumed run-off of funds occurring in a stress scenario over a 30-day period. A ratio of $100 \%$ or greater would imply that the bank is able to meet the run-off by selling off HQLAs.

The fundamental problem is that the numerator of the LCR includes assets that depend on secondary markets for liquidity. The haircuts attempt to reflect liquidity quality differences, and can be interpreted as implying a liquidity weight for each type of asset. There is no empirical or theoretical basis for such "weighting", and these assets are most likely to become illiquid in a crisis when markets cease to function well.

Concerning the dominator of the LCR, the fundamental problem is that it has no clear relationship to any particular degree of stress, while the SLI is based on a well-defined degree of stress.

In summary, in the view of the shadow committees, the SLI dominates the LCR proposed by the Basel Committee. The SLI is easier to measure, verify, and administer by financial market regulators. From the perspective of all financial market participants, it imposes lower compliance costs. The SLI may easily be applied to estimate the impact of stress, while its simplicity in estimation and clarity reduce asymmetries in information between market participants. It also facilitates comparisons across peer groups of banks and for the same bank over time. In addition, it avoids the unintended consequences of imposing a regulatory minimum that may interact in complex ways with changes in asset prices in an already complicated financial regulatory structure. Finally, the SLI offers the advantage of greater reliance on market discipline, rather than a uniform regulatory minimum, and it facilitates comparisons between differences in business models across banks in the present and over time.

\section{Concluding Remarks}

Although bank capital ratios have risen significantly since the recent financial crisis, they are still at historically low levels, as shown by the historical empirical evidence discussed in this paper. In a world in which global debt ratios have risen even further during the past decade, this is a worrying signal of fragility in the global financial system.

Moreover, the outbreak of the coronavirus crisis in early 2020 resulted in bank stock prices falling substantially. Similarly to the GFC of 2007-2009, central banks, and notably the Federal Reserve and the European Central Bank (ECB), had to resort to substantial emergency measures such as a reduction in interest rates, liquidity support for banks, and purchases of government and other debt. There is real concern about the stability of the banking sector and the financial system at large. Banks may be facing losses in their loan portfolios that could overwhelm their capital base. Further, concerns about bank solvency may lead to liquidity crises.

The corona crisis clearly demonstrates that, notwithstanding the progress made under the implementation of Basel III, the banking and financial system is still very fragile and prone to crises. Bank capitalization levels are apparently a matter of concern to investors in financial markets.

Therefore, after the corona crisis, we need to be much more ambitious in raising bank capital levels, preferably in the form of Tier 1 equity capital ratio.An increase toward a ratio of $10-15 \%$ would be consistent with bank capital ratios that were common before the introduction of guarantees, such as deposit insurance and too big to fail, after the banking crisis in the 1930s.

It is interesting to note that among leading scholars in the banking literature, as exemplified by the papers discussed in this article, there is general agreement that bank capital levels are still relatively low, even after the implementation of the Basel III Accord. The corona crisis is a new and urgent 
wake-up call. Hopefully, bankers and regulators will be able and willing to learn lessons from this new crisis and start working on a more robust financial system with higher buffers.

Funding: This research received no external funding.

Conflicts of Interest: The authors declare no conflicts of interest.

\section{References}

Admati, Anat, and Martin Hellwig. 2010. The Bankers' New Clothes: What's Wrong with Banking and What to Do about It. Princeton: Princeton University Press.

Basel Committee on Banking Supervision. 1988. International Convergence of Capital Measurement and Capital Standards. Basel: Basel Committee on Banking Supervision.

Basel Committee on Banking Supervision. 2004. International Convergence of Capital Measurement and Capital Standards-A Revised Framework. Basel: Basel Committee on Banking Supervision.

Basel Committee on Banking Supervision. 2010a. Basel III: A Global Regulatory Framework for More Resilient Banks and Banking Systems. Basel: Basel Committee on Banking Supervision.

Basel Committeee on Banking Supervision. 2010b. Basel III: International Framework for Liquidity Risk Measurement, Standards and Monitoring. Basel: Basel Committee on Banking Supervision.

Basel Committee on Banking Supervision. 2017. Basel III: Finalizing Post-Crisis Reforms. Basel: Basel Committee on Banking Supervision.

Benink, Harald A., ed. 1995. Coping with Financial Fragility and Systemic Risk. Boston, Dordrecht and London: Kluwer Academic Publishers.

Benink, Harald A. 1996. Financial Fragility. Ph.D. thesis, Maastricht University, Maastricht, The Netherlands.

Benink, Harald A., and George J. Benston. 2005. The Future of Banking Regulation in Developed Countries: Lessons from and for Europe. Financial Markets, Institutions \& Instruments 14: 289-328.

Benink, Harald A., and George G. Kaufman. 2008. Turmoil Reveals the Inadequacy of Basel II. Financial Times, February 28.

Benink, Harald A., and Clas Wihlborg. 2002. The New Basel Capital Accord: Making It Effective with Stronger Market Discipline. European Financial Management 8: 103-15. [CrossRef]

Carletti, Elena, Itay Goldstein, and Agnese Leonello. 2018. The Interdependence of Bank Capital and Liquidity. Working Paper.

Crockett, Andrew D. 1995. Financial Fragility: Sources, Prevention and Treatment. In Coping with Financial Fragility and Systemic Risk. Edited by Harald A. Benink. Boston, Dordrecht and London: Kluwer Academic Publishers, pp. 267-77.

DeYoung, Robert, Isabelle Distinguin, and Amine Tarazi. 2018. The Joint Regulation of Bank Liquidity and Bank Capital. Journal of Financial Intermediation 34: 32-46. [CrossRef]

European Shadow Financial Regulatory Committee. 2014. Complexity and Credibility in the Single Resolution Mechanism. Statement No. 39. London: European Shadow Financial Regulatory Committee.

European Shadow Financial Regulatory Committee. 2016. Towards Banking Union and Capital Markets Union in Europe: The Role of Shadow Banks. Statement No. 41. Brussels: European Shadow Financial Regulatory Committee.

Goodhart, Charles. 2008. Liquidity Risk Management. Financial Stability Review 11: 39-44.

Greenspan, Alan. 2008. Banks Need More Capital. The Economist, December 18.

Kaufman, George G. 1994. Bank Contagion: A Review of the Theory and Evidence. Journal of Financial Services Research 8: 123-50. [CrossRef]

Knight, Frank K. 1921. Risk, Uncertainty and Profit. Chicago: University of Chicago Press, Published in Book form in 1992.

Miller, Merton H. 1988. The Modigliani-Miller Propositions after Thirty Years. Journal of Economic Perspectives 2: 99-120. [CrossRef]

Miller, Merton H. 1991. Leverage. Journal of Finance 46: 479-88. [CrossRef]

Minsky, Hyman P. 1977. A Theory of Systemic Fragility. In Financial Crises: Institutions and Markets in a Fragile Environment. Edited by Edward I. Altman and Arnold W. Sametz. New York: John Wiley \& Sons, pp. 138-52.

PricewaterhouseCoopers. 2018. 'Basel IV': The Output Floor. London: PricewaterhouseCoopers. 
Rajan, Raghuram G. 2010. Fault Lines, How Hidden Fractures Still Threaten the World Economy. Princeton: Princeton University Press.

Shadow Financial Regulatory Committees of Asia, Australia-New Zealand, Europe, Japan, Latin America and the United States. 2013. Misdiagnosis of Crisis has led to Botched Liquidity Regulation. Joint Statement No. 10. Tokyo: Shadow Financial Regulatory Committees of Asia, Australia-New Zealand, Europe, Japan, Latin America and the United States, October 28.

Thakor, Anjan V. 2018. Post-Crisis Regulatory Reform in Banking: Address Insolvency Risk, not Illiquidity! Journal of Financial Stability 37: 107-11. [CrossRef]

Wolf, Martin. 2014. Financial Reform: Call to Arms. Financial Times, September 3.

(C) 2020 by the author. Licensee MDPI, Basel, Switzerland. This article is an open access article distributed under the terms and conditions of the Creative Commons Attribution (CC BY) license (http://creativecommons.org/licenses/by/4.0/). 